\title{
Pengaruh Penambahan Tepung Temulawak (Curcuma xanthoriza) Dalam Ransum Terhadap Performa Produksi Ayam Kampung Unggul Balitnak
}

\section{The Effects of Temulawak Flour (Curcuma xanthoriza) as Natural Feed Additive on The Performance of Kampung Unggul Balitnak Chicken}

\author{
Trisno Agung Wibowo ${ }^{1}$, Wati NE${ }^{1}$, Suhadi $\mathrm{M}^{1}$ \\ ${ }^{1}$ Fakultas Peternakan, Universitas Tulang Bawang Lampung. Jl. Gajah Mada No.34 \\ Kotabaru, Bandar Lampung \\ aagungwibowo112@gmail.com
}

\begin{abstract}
The aim of the study was to know the effect of Curcuma xanthorhiza as herbal feed additive on feed consumption, daily body weight gain and feed conversion ratio of Kampung Unggul Balitnak (KUB) Chicken. The research was conducted at Kemukus Village, Ketapang District, South Lampung Regency. The experimental used 80 unisex KUB chicken aged 5 week. They were feed a ration with control ration $+0 \%$ temulawak flour $(\mathrm{P} 0)$, control ration $+0,1 \%$ temulawak flour (P1), control ration + $0,2 \%$ temulawak flour (P2) and control ration $+0,3 \%$ temulawak flour (P4) during 30 days. The control ration containing $21 \%$ crude protein and $3150 \mathrm{kcal} / \mathrm{kg}$ metabolism energy. The study used a quantitative method with completely randomized design with 4 treatments and 4 replications. The results showed that the addition of temulawak flour (Curcuma xanthoriza) up to $0.3 \%$ did not effect $(P>0.05)$ on feed consumption but was affected $(P<0.05)$ on daily body weight gain and feed conversion ratio.
\end{abstract}

Keywords: daily body weight gain, feed consumption, feed conversion ratio, KUB Chicken, temulawak

\section{PENDAHULUAN}

Peningkatan jumlah penduduk berpengaruh terhadap peningkatan permintaan bahan pangan hewani sumber protein yang terdiri dari susu, telur dan daging. Daging merupakan salah satu komoditi pertanian yang diperlukan untuk memenuhi kebutuhan protein, karena daging mengandung protein yang bermutu tinggi, yang mampu menimbang asam amino esensial yang lengkap. Khususnya Permintaan daging ayam kampung semakin meningkat dari tahun ke tahun, yang di indikasikan dengan semakin banyaknya warung dan rumah makan yang menghidangkan menu ayam kampung (Bakrie et al., 2003). Berdasarkan data dari Direktorat Jenderal Peternakan dan Kesehatan Hewan Kementerian Pertanian RI tahun 2018, konsumsi daging ayam kampung mengalami peningkatan pada setiap tahunnya. Pada tahun 2016, konsumsi daging ayam kampung mengalami peningkatan dari 0,626 kg/kapita/tahun menjadi 0,782 kg/kapita/tahun pada tahun 2017.

Permintaan daging ayam kampung dapat dipenuhi dengan peningkatan produksi ayam kampung. Peningkatan produksi ayam kampung dapat dilakukan dengan peningkatan kuantitas dan peningkatan kualitas yaitu dengan perbaikan pakan. Pakan merupakan salah satu faktor yang sangat penting bagi kelangsungan bisnis peternakan, karena biaya pakan merupakan biaya terbesar yang dikeluarkan oleh usaha peternakan. Pada pola pemeliharaan intensif, biaya produksi ternak terbesar berasal dari pakan yaitu sebesar 60-79\%. Upaya untuk meningkatkan produktivitas ayam Kampung Unggul Balitnak salah satunya dengan menambahkan pakan aditif yaitu tepung temulawak.

Temulawak merupakan salah satu rimpang asli indonesia yang banyak digunakan sebagai jamu baik pada manusia atau hewan ternak. Komponen utama kandungan zat yang terdapat dalam rimpang temulawak adalah zat kuning yang disebut kurkumin dan juga protein, pati serta zat-zat minyak atsiri. Kandungan kurkumin dalam rimpang temulawak berkisar 1,6 
- 2,22 \%. Minyak atsiri dan kurkumin mempunyai khasiat merangsang sel hati untuk meningkatkan produksi empedu dan memperlancar sekresi empedu. Hal ini akan mengurangi partikel-partikel padat yang terdapat dalam kantung empedu. Empedu berfungsi melarutkan lemak dengan lancarnya sekresi empedu dan menurunkan kadar kolestrol dan pencernaan serta penyerapan lemak berjalan lancar.

Kurkumin berpengaruh pada pankreas dan meningkatkan nafsu makan. Temulawak dapat mempercepat pengosongan lambung. sehingga timbul rasa lapar dan merangsang nafsu makan (Wijayakusuma, 2003). Kurkumin dan minyak atsiri pada temulawak secara fisik dan kimia mempunyai potensi sebagai feed additive pada pakan ternak untuk tujuan meningkatkan produktivitas, kualitas produk dan kesehatan (Aziz, 2005).

Penambahan tepung temulawak pada Ayam Kampung Unggul Balitnak diharapkan dapat meningkatkan konsumsi pakan, pertambahan bobot badan harian (PBBH) dan konversi pakan.

\section{MATERI DAN METODE}

\section{Materi Penelitian}

Alat yang digunakan dalam penelitian ini adalah kandang, timbangan dengan ketelitian 1 g digunakan untuk menimbang pakan dan ayam, wadah pakan, wadah air minum, ember kecil, lembar pengamatan, kamera dan alat tulis. Bahan yang digunakan dalam penelitian ini meliputi 80 ekor ayam Kampung Unggul Balitnak berumur 5 minggu, yang diberi perlakuan selama 30 hari. Ayam ditempatkan dalam 4 petak kandang sesuai dengan jumlah perlakuan. Setiap petak kandang perlakuan dibagi menjadi 4 bagian sebagai ulangan. Setiap ulangan terdapat 5 ekor ayam Kampung Unggul Balitnak. Perlakuan yang diberikan adalah :

$\mathrm{PO}=$ pakan kontrol $+0 \%$ tepung temulawak

$\mathrm{P} 1=$ pakan kontrol $+0,1 \%$ tepung temulawak

P2 = pakan kontrol $+0,2 \%$ tepung temulawak

P3 $=$ pakan kontrol $+0,3 \%$ tepung temulawak

Pakan kontrol yang digunakan adalah konsentrat jadi merk Bongsor AB-02 yang diproduksi oleh PT. Agro Sari Nusantara, kandungan nutrien pakan tersaji pada Tabel 1.

Tabel 1. Kandungan Nutrien Pakan Merk Bongsor AB-02

\begin{tabular}{lc}
\hline \hline Nutrien & Jumlah \\
\hline Energi metabolisme (kkal/kg) & $3000-3150$ \\
Protein kasar (\%) & 21 \\
Serat kasar (\%) & 4,0 \\
Lemak (\%) & 7 \\
Kalsium/Ca (\%) & $0,8-1,1$ \\
Fosfor (\%) & 0,5 \\
Abu (\%) & 7,0 \\
Kadar air (\%) & 13 \\
\hline
\end{tabular}

Sumber : PT. Agro Sari Nusantara (2019)

\section{Metode Penelitian}

Ayam Kampung Unggul Balitnak berumur 5 minggu dan diberi perlakuan selama 30 hari. Perlakuan yang diberikan adalah $\mathrm{P} 0=$ pakan kontrol $+0 \%$ tepung temulawak, $\mathrm{P} 1=$ pakan kontrol $+0,1 \%$ tepung temulawak, $\mathrm{P} 2=$ pakan kontrol $+0,2 \%$ tepung temulawak, dan $\mathrm{P} 3=$ pakan kontrol $+0,3 \%$ tepung temulawak. Pemberian pakan, dilakukan 2 kali dalam satu hari pada pagi hari pukul 07.30 WIB dan sore hari pada pukul $15.00 \mathrm{WIB}$, penimbangan sisa pakan yang dilakukan setiap pagi hari, penimbangan bobot badan ayam dilakukan pada awal dan akhir penelitian. 


\section{Analisis Data}

Model linear ulangan seluruh nilai pengamatan dengan rancangan acak lengkap adalah sebagai berikut :

$Y i j=\mu+\mathrm{tj}+\epsilon i j$

Keterangan :

$Y_{i j}=$ Hasil pengamatan konsumsi paka, pertambahan bobot badan dan konversi pakan ke i (P0, P1, P2, P3) dengan ulangan ke - j $(1,2,3,4)$.

$\mathrm{i}=$ Perlakuan penambahan tepung temulawak.

$\mathrm{j} \quad=$ Ulangan ke 1, 2, 3 dan 4.

$\mu=$ Rataan ulangan/nilai tengah.

тj = Pengaruh perlakuan penambahan tepung temulawak.

$\epsilon_{\mathrm{ij}}=$ Pengaruh galat percobaan dengan perlakuan penambahan tepung temulawak (P0, P1, $\mathrm{P} 2$ dan $\mathrm{P} 3)$ dengan ulangan $\mathrm{ke}-\mathrm{j}(1,2,3,4)$.

Hipotesis statistik yang diuji adalah :

$\mathrm{H}_{0}=\mathrm{T}_{1}=\mathrm{T}_{2}=\mathrm{T}_{3}=0$, tidak terdapat pengaruh penambahan tepung temulawak pada ransum terhadap konsumsi pakan, pertambahan bobot badan dan konversi pakan Ayam Kampung Unggul Balitnak.

$\mathrm{H}_{1}=$ Minimal ada satu $\mathrm{T}_{1} \neq 0$, terdapat pengaruh penambahan tepung temulawak pada ransum terhadap konsumsi pakan, pertambahan bobot badan dan konversi pakan Ayam Kampung Unggul Balitnak.

Data hasil penelitian diuji $\mathrm{F}$ berdasarkan prosedur sidik ragam dan dilanjutkan dengan uji jarak berganda Duncan (UJGD) pada taraf 5\% dibantu dengan perangkat lunak SPSS version 17.00 untuk mengetahui pengaruh penambahan tepung temulawak terhadap konsumsi pakan, pertambahan bobot badan dan konversi pakan. Kriteria mengambil keputusan adalah apabila nilai probabilitas $\mathrm{P}<0,05$, maka ada pengaruh penambahan tepung temulawak terhadap konsumsi pakan, pertambahan bobot badan dan konversi pakan dan sebaliknya apabila nilai probabilitas $P>0,05$, maka tidak ada pengaruh penambahan tepung temulawak terhadap konsumsi pakan, pertambahan bobot badan dan konversi pakan.

\section{HASIL DAN PEMBAHASAN}

\section{Pengaruh Perlakuan Terhadap Konsumsi Pakan}

Hasil penelitian menunjukkan bahwa penambahan tepung temulawak (Curcuma xanthoriza) pada pakan ayam Kampung Unggul Balitnak tidak berpengaruh nyata $(P>0,05)$ terhadap konsumsi pakan ayam. Besarnya konsumsi pakan ayam yang mendapat perlakuan P0, P1, P2 dan P3 tersaji pada Tabel 2.

Tabel 2. Penambahan Tepung Temulawak Terhadap Konsumsi Pakan Ayam KUB

\begin{tabular}{lcc}
\hline Perlakuan & Rataan g/ekor/hari & Standar Deviasi \\
\hline P0 & 69,66 & 0,56 \\
P1 & 71,78 & 0,66 \\
P2 & 69,59 & 0,34 \\
P3 & 72,57 & 1,61 \\
\hline
\end{tabular}

Keterangan: Superskrip yang berbeda pada kolom yang sama menunjukan pengaruh yang tidak nyata pada taraf $5 \%(P>0,05) . P 0=$ pakan kontrol $+0 \%$ tepung temulawak; $P 1=$ pakan kontrol $+0,1 \%$ tepung temulawak; $\mathrm{P} 2=$ pakan kontrol $+0,2 \%$ tepung temulawak; $\mathrm{P} 3=$ pakan kontrol $+0,3 \%$ tepung temulawak. 
Rataan konsumsi pakan ayam Kampung Unggul Balitnak dengan penambahan tepung temulawak P0, P1, P2 dan P3 tidak berbeda nyata yaitu berturut-turut sebesar 69,66 g, 71,78 $\mathrm{g}$, dan $69,59 \mathrm{~g}$, dan $72,57 \mathrm{~g}$. Hasil ini menunjukkan bahwa penambahan tepung temulawak hingga dosis $0,3 \%$ belum menunjukkan peningkatan konsumsi pakan pada ayam Kampung Unggul Balitnak. Kurkumin dan atsiri pada temulawak yang ditambahkan belum memberikan pengaruh terhadap nafsu makan sehingga konsumsi tidak berbeda nyata. Hasil penelitian Anggraini et al (2019) menunjukkan bahwa tepung temulawak yang ditambahkan ke dalam pakan dengan dosis $1 \%$ belum dapat meningkatkan konsumsi pakan. Hasil penelitian Wiryawan et al (2005) juga menyebutkan bahwa penambahan tepung temulawak ke dalam pakan ayam broiler dengan dosis $0,05 \%$ tidak memberikan pengaruh yang nyata terhadap konsumsi pakan. Besarnya konsumsi pakan ayam Kampung Unggul Balitnak yang dipelihara sesuai dengan yang standar konsumsi pakan ayam kampung umur 6,7,8 dan 9 minggu yaitu sebesar $66 \mathrm{~g}, 729 \mathrm{~g}, 74 \mathrm{~g}$ dan $80 \mathrm{~g}$ (Yusriani, 2013).

\section{Pengaruh Perlakuan Terhadap Pertambahan Bobot Badan Harian}

Hasil penelitian menunjukkan bahwa penambahan tepung temulawak (Curcuma xanthoriza) pada pakan ayam Kampung Unggul Balitnak berpengaruh nyata $(P<0,05)$ terhadap pertambahan bobot badan harian ayam. Besarnya pertambahan bobot badan harian ayam yang mendapat perlakuan P0, P1, P2 dan P3 tersaji pada Tabel 3.

Tabel 3. PBBH Ayam KUB dengan Penambahan Tepung Temulawak Dalam Pakan

\begin{tabular}{lcc}
\hline \hline Perlakuan & Rataan g/ekor/hari & Standar Deviasi \\
\hline P0 & $15,38^{\mathrm{a}}$ & 1,38 \\
P1 & $18,45^{\mathrm{b}}$ & 2,61 \\
P2 & $17,34^{\mathrm{ab}}$ & 0,94 \\
P3 & $18,90^{\mathrm{b}}$ & 1,07 \\
\hline
\end{tabular}

Keterangan: Superskrip yang berbeda pada kolom yang sama menunjukan pengaruh yang nyata pada taraf $5 \%(\mathrm{P}<0,05) . \mathrm{P} 0=$ pakan kontrol $+0 \%$ tepung temulawak; $\mathrm{P} 1=$ pakan kontrol $+0,1 \%$ tepung temulawak; P2 $=$ pakan kontrol $+0,2 \%$ tepung temulawak; $\mathrm{P} 3=$ pakan kontrol $+0,3 \%$ tepung temulawak

Rataan pertambahan bobot badan harian ayam KUB yang diberi perlakuan penambahan tepung temulawak paling tinggi pada $\mathrm{P} 3, \mathrm{P} 1$ yaitu sebesar $18,90 \mathrm{~g}$ dan $18,45 \mathrm{~g}$. Sedangkan besarnya pertambahan bobot badan harian ayam P2 $(17,34 \mathrm{~g})$ tidak berbeda nyata dengan P1 (18,45 g), P3 (18,90 g) dan P0 (15,38 g). Ayam P0 menghasilkan PBBH terendah yaitu $15,38 \mathrm{~g}$. Hasil penelitian menunjukkan bahwa penambahan tepung temulawak hingga dosis $0,3 \%$ dapat meningkatkan PBBH pada ayam Kampung Unggul Balitnak. Pertambahan bobot badan harian yang berbeda kemungkinan disebabkan oleh sinar matahari di lingkungan kandang. Kandang memanjang ke arah barat ke timur, sehingga kandang terkena sinar matahari dari arah timur ke barat khususnya pada waktu pagi. Sinar matahari pagi baik untuk kesehatan terutama pembentukan pro vitamin $D$ yang sangat dibutuhkan untuk pertumbuhan ayam. Hal ini sesuai dengan pendapat Johari (2004) bahwa sinar matahari pagi mengandung vitamin $\mathrm{D}$ yang bagus untuk pertumbuhan.

Meskipun konsumsi pakan tidak berbeda nyata. Hasil penelitian Anggraini et al (2019) menunjukan bahwa penambahan tepung temulawak dalam pakan ayam kampung super dengan dosis $0,33 \%$ dapat meningkatkan pertambahan bobot badan. Hasil penelitian Rositawati et al (2010) menunjukan bahwa penambahan tepung temulawak dengan level $0,2 \% / \mathrm{kg}$ pakan memberikan respon terbaik terhadap $\mathrm{PBBH}$ dan berbanding lurus dengan konversi pakan. Pertambahan bobot badan harian ayam Kampung Unggul Balitnak yang dipelihara lebih tinggi daripada standar PBBH ayam kampung pada umur 6,7,8 dan 9 minggu yaitu sebesar 500 g, 600 g, $700 \mathrm{~g}$ dan $800 \mathrm{~g}$ (Aryanti et al., 2013). 


\section{Pengaruh Perlakuan Terhadap Konversi Pakan}

Hasil penelitian menunjukkan bahwa penambahan tepung temulawak (Curcuma xanthoriza) pada pakan ayam Kampung Unggul Balitnak berpengaruh nyata $(P<0,05)$ terhadap konversi pakan. Besarnya konversi pakan ayam yang mendapat perlakuan P0, P1, P2 dan P3 tersaji pada Tabel 4.

Tabel 4. Konversi Pakan Ayam KUB dengan Penambahan Tepung Temulawak Dalam Pakan

\begin{tabular}{lcc}
\hline \hline Perlakuan & Rataan & Standar Deviasi \\
\hline P0 & $4,54^{\mathrm{b}}$ & 0,22 \\
P1 & $3,94^{\mathrm{ab}}$ & 0,49 \\
P2 & $4,02^{\mathrm{ab}}$ & 0,26 \\
P3 & $3,84^{\mathrm{a}}$ & 1,20 \\
\hline
\end{tabular}

Keterangan: Superskrip yang berbeda pada kolom yang sama menunjukan pengaruh yang nyata pada taraf $5 \%(P<0,05)$. $)$. $P 0=$ pakan kontrol $+0 \%$ tepung temulawak; $P 1=$ pakan kontrol $+0,1 \%$ tepung temulawak; $\mathrm{P} 2$ = pakan kontrol $+0,2 \%$ tepung temulawak; P3 = pakan kontrol $+0,3 \%$ tepung temulawak

Rataan konversi pakan ayam Kampung Unggul Balitnak yang diberi perlakuan penambahan tepung temulawak paling tinggi pada P0 yaitu sebesar $4,54 \mathrm{~g}$ konversi pakan P0 berbeda nyata dengan P3. Sedangkan konversi pakan ayam P3 paling efisien yaitu 3,84 g. Besarnya konversi pakan ayam P1 $(3,94)$, P2 $(4,02)$, tidak berbeda nyata dengan P3 $(3,84)$ dan P0 (4,54). Hasil tersebut menunjukan bahwa ayam P3 menghasilkan konversi pakan terbaik. Hal ini disebabkan karena ayam P3 menghasilkan PBBH terbaik meskipun konversi pakan sama. Hal ini sesuai dengan pendapat Haruna (2008) bahwa semakin tinggi nilai bobot badan pada tingkat konsumsi yang sama maka konversi pakan semakin efisien. Sejalan dengan pendapat Sulaeman et al (2015) bahwa konversi pakan dipengaruhi oleh tingkat konsumsi pakan dan peningkatan pertambahan bobot badan. Rataan konversi pakan ayam kampung yang dipelihara lebih tinggi daripada standar konversi pakan. Konversi pakan ayam kampung pada umur 6,7,8 dan 9 minggu yaitu sebesar 2,81, 1,99, 2,04 dan 2,16 (Aryanti et al., 2013).

\section{KESIMPULAN}

Berdasarkan hasil penelitian yang dilakukan dapat disimpulkan bahwa penambahan tepung temulawak (Curcuma xanthoriza) sampai level 0,3\% dalam pakan ayam Kampung Unggul Balitnak tidak berpengaruh terhadap konsumsi pakan namun berpengaruh terhadap pertambahan bobot badan harian dan konversi pakan. Dari hasil penelitian dapat disarankan bahwa perlu dilakukan penelitian lanjut dengan meningkatkan dosis penambahan tepung temulawak untuk menghasilkan produktivitas ayam KUB yang optimal.

\section{DAFTAR PUSTAKA}

Anggraini, D. A., Widodo. W., Rahayu, D.I dan Sutanto. A. 2019. Efektifitas Penambahan Tepung Temulawak Dalam Ransum Sebagai Upaya Peningkatan Produktifitas Ayam Kampung Super. Jurnal Sains Peternakan Indonesia. Universitas Muhamadiyah Malang, Jawa Timur.

Aryanti, F., M. Aji dan N., Budiono N. 2013. Pengaruh pemberian air gula merah terhadap performans ayam kampung pedaging. Sains Veteriner. 31. (2) : 0126-0421.

Aziz, N. K. 2005. Potensi Temulawak dalam Peningkatan Produktifitas Ternak. Riset. Poultry Indonesia. Edisi 302: 68-69.

Bakrie, B., D. Andayani, M. Yanis dan D. Zainudin. 2003. Pengaruh Penambahan Jamu ke dalam Air Minum terhadap Preferensi Konsumen dan Mutu Karkas Ayam Buras. 
Prosiding Seminar Nasional Teknologi Peternakan dan Veteriner. Puslibang Peternakan, Bogor.

Haruna. 2008. Pemanfaatan Jamu Sebagai Campuran Air Minum Pada Ternak Puyuh. Jurnal Agrisistem. 4 (1) : 1-11.

Jaelani, A. 2011. Performans Ayam Pedaging Diberi Enzim Beta Mannanase dalam Ransum yang Berbasis Bungkil Inti Sawit. Skripsi Peternakan. Jurusan Peternakan. Fakultas Peternakan. Universitas Islam Kalimantan, Kalimantan Selatan.

Johari, R. (2004). Efficiency loss in market mechanisms for resource allocation (Doctoral dissertation, Massachusetts Institute of Technology).

Rasyaf, M. 2011. Panduan Beternak Ayam Pedaging. Cetakan ke - 4 Penebar Swadaya, Jakarta.

Rositawati. I. N. Saiful dan Muharlien. 2010. Upaya Peningkatan Performan Itik Mojosari Periode Starter Melalui Penambahan Temulawak (Curcuma xanthoriza) Pada Pakan. Ternak Tropikal. Universitas Brawijaya Malang. 11 (2). : 3.2 - 40.

Sugiyono, D. (2010). Metode penelitian kuantitatif kualitatif dan R\&D. Bandung: Alfabeta.

Sulaeman, Y., Ropik, S., Bachri, S., Sutriadi, M. T., \& Nursyamsi, D. 2015. Sistem informasi sumberdaya lahan pertanian Indonesia: status terkini dan arah pengembangan ke depan.

Wijayakusuma, H. 2003. Penyembuhan dengan Temulawak. Milenial Populer, Jakarta.

Wiryawan, K.G. Suharti dan M. Bintang. 2005. Kajian Antibakteri Temulawak, Jahe dan Bawang Putih Terhadap Performans dan Respon Imun Ayam Pedaging. Media Peternakan. 28 (2) : 52-62.

Yusriani, Y. 2013. Kebutuhan Pakan untuk Ayam Kampung. Serambi Pertanian. Balai Pengkajian Teknologi Pertanian, Aceh. 